\title{
Review of Nicola Phillips, The Profligate Son: Or, A True Story of Family Conflict, Fashionable Vice and Financial Ruin in Regency Britain (Basic Books, 2013)
}

The narrative of "the rake's progress" was all too familiar to Georgian Britons. Today, we would probably think of William Hogarth's famous series of eight images, which depict Tom Rakewell's "progress" from newfound wealth to poverty and insanity, via sexual immorality, social pretension, drink, gaming, debt, and criminality. At the time, this was a stock cautionary tale, which was reiterated in sermons, novels, and advice literature. It was the product of a society where social standing was, for the first time, up for grabs to those who could present themselves in a certain way and negotiate the complex rules of polite society - but where, at the same time, reputation was fragile and fortunes could quickly be dashed. The rake's progress therefore functioned as a warning, steering Georgians away from vice and keeping them on the straight path to the good life.

If ever there was a real-life embodiment of the rake's progress, it would appear to be William Jackson. He is the subject of Nicola Phillips's superb new book, which takes the form of a biography but also uses the life of Jackson-and also those around himto explore various aspects of late-Georgian social, criminal, imperial, and sexual history. William was the son of a colonial administrator who had worked for the East India Company in Madras. His family were therefore new money, and his father combined the stern morality of the middle classes with a burning ambition to become accepted by the establishment. (As Phillips points out, Jackson senior's high opinion of himself is ironically in stark contrast to his reputation in Indian historiography, where he is demonized as "an archetypical arrogant British official" [276]). As is often the way with the newly wealthy, his plans for respectability focused on his son. William, however, was unpromising material for such a scheme, and The Profligate Son tells the story of the terrible consequences that it would have for father and son alike.

Without wishing to spoil Phillips's story, it is useful briefly to relate Jackson's life story, as he was not a well-known figure. William Collins Burke Jackson was born in India in 1791. He was a slight boy with a weak constitution, which would be severely tested by some of the predicaments in which he was to find himself. On the family's return to England, his father set about trying to place William in a school, with a view to easing his entry into elite society but also where he would receive instruction in suitable moral discipline. Brief spells followed at a succession of establishments, where he rebelled against his tutors, acquired enemies and unsuitable friends, and began a lifetime's habit of running up debts. Where school failed, his father hoped that a commission in the army might succeed, but the outcome was similar: instead of discipline and responsibility, Jackson took full advantage of the army's opportunities for fashionable high living, and of the further credit that he could acquire on the strength of his uniform. Phillips describes how Jackson's schooling and military career ironically exposed him to an aristocratic lifestyle and morality that was in direct opposition to the bourgeois values of his father.

Eventually, Jackson's debts caught up with him and he served spells in debtors' prisons. Phillips offers a vivid account of life in these quintessentially Georgian institutions, where those with money could buy a higher standard of living: even at his lowest ebb, Jackson refused to relinquish his pretensions to gentility. Of course, his financial situation could always have been solved at a stroke by the intercession of his wealthy father, but Jackson senior was adamant that William was the author of his own misfortune and should learn his lesson. This did not happen, however, and he resorted 
to fraud and forgery as his situation became more desperate. Remarkably, his father even refused him assistance when he was up for a potentially capital charge at the assizes. When he was sentenced to transportation-which was in effect a civil death, as the prisoner was removed both legally and physically from society - his father could wash his hands of him entirely. In Australia, Jackson had an opportunity to start again. He acquired many of the trappings of respectability: crucially, he married and had a son of his own (who, in many respects, would go on to live the life that his own father had desired for him). On his father's death, a substantial inheritance promised to set Jackson up for life, but lengthy complications in the court of Chancery and the actions of an unscrupulous lawyer meant that he died poor and mad with drink on the streets of Sydney in March 1828. The story of the rake's progress therefore came to its inevitable end, with additional echoes of Dickens's Bleak House.

Phillips has been able to piece together the life story of the otherwise obscure Jackson because of the existence of a remarkable document by his father, entitled Filial Ingratitude: Or, The Profligate Son (from which she has taken her title). Written between 1807 and 1814, its three volumes assemble the huge number of letters that passed between Jackson and family members, along with his father's comments and descriptions of events. It was never published, although at one point his father threatened to do so if he did not reform his behaviour: instead, it became an extensive dossier that detailed his son's "ingratitude" and "profligacy," and justified the father's actions in response. In a sense, Phillips's book is a biography based on a biography, but she also uses many other primary sources as well, including, crucially, Jackson's correspondence with his far more sympathetic mother. There is also extensive engagement with current secondary literatures to flesh out the context of Jackson's story, especially where the history of crime is concerned. Following Jackson's transportation, and especially following the death of the father who had documented his life, the sources on Jackson himself become thin, so Phillips concentrates more on the nature of colonial society. Instead, we hear more about his associates such as Mr. Eagar, the lawyer who swindled him.

Phillips's wider work is on the history of gender, and The Profligate Son will be of great interest to scholars of masculinity and the family. It is rare, and therefore especially valuable, to have questions of masculinity explored over the course of the lifecycle and between generations. The relationship between father and son is the crux of the book: not only the two protagonists in question, but more generally in Georgian society. The relationships between governors and governed, colonizers and colonized, judge and defendant were negotiated in essentially patriarchal terms. Phillips acknowledges that today we would have less sympathy for the moral judgments of the father, and would recognize in William "the destructive behaviour of a deeply flawed individual" (272): indeed, in the wake of the psychological sciences, we might even be inclined to blame the latter on the former. Only by exploring the world in which these two men lived can we gain some understanding of their life stories. Phillips's combination of biography and social history is therefore the ideal way into this remarkable rake's progress. 